\title{
Inflation Theories and Inflation Persistence in Iran
}

\section{Hamidreza Ghorbani Dastgerdi *}

\begin{abstract}
This study focuses on: (1) finding the causes of inflation which follows the inflation theories such as Demand-Pull, Cost-Push and Structural inflation.(2) measuring the degree of inflation persistence in order to evaluate the ability of monetary policies to control inflation. Engle-Granger test and the Autoregressive Distributed Lag are applied to analyze the response of inflation to its determinants. The Grid bootstrap Method and Impulse Response Functions measure the inflation persistence. The results suggest that controlling the money supply is a key factor in controlling inflation. The appreciation of Rial exchange rate is an important factor of low inflation. It is increased as a result of Budget deficit while decreased due to oil price and real GDP. Inflation persistence follows the structural changes and finally permanent shocks die out after some horizons. Therefore, monetary authorities control inflation but their policies are yet far from optimal level.
\end{abstract}

Keywords: inflation; inflation theories; inflation persistence

JEL Classification: E3, E6

\section{Introduction}

Inflation is one of the biggest challenges for governments and policy makers since World War I and II because of its large adverse effects on economy and people in particular; It increases poverty and crime rates. There is consensus among scholars and policy makers about the cost of inflation which includes economic costs, social unrest and income inequalities. However, a large disagreement exists among them about causes and controlling policies of inflation. Every school of thought has its own explanation about the reasons of the phenomenon. Inflation theories have developed the causes of inflation in parallel with the new events and economic crises. German's inflation of 1922-1923 (after World War I) for instance, is a classic example of demand-pull inflation caused by the increase in the money supply.

${ }^{*}$ Hamidreza Ghorbani Dastgerdi is at Department of Economics, COMSATS University Islamabad, Lahore Campus, Lahore, Pakistan 
After World War I and II, the high inflation also surfaced in the 1958-recession in Western countries. In this particular crisis, aggregate demand had fallen. Hence, the general price index should have reduced but it really did not. The consumer price index (CPI) actually proceeds to increase, with a high rate of unemployment. An attempt to find the reason of this particular phenomenon, mainly for the 1958-puzzle, has contributed to the emergence of supply-side theories of inflation, commonly wellknown as cost-push theory and supply-shock theory of inflation.

Also in the 1970s, a great number of nations experienced the high levels of both inflation and unemployment referred to as stagflation. Theories based on the Phillips curve advocated that this cannot occur; so it came under criticism by several economists. In 1977, Nobel Prize was awarded to Friedman (1977) for his criticism of the Phillips curve (Buchanan et al., 2013). Stagflation happened because most of the oil-importing countries were confronted suddenly with an increase in oil prices during Arab-Israel War. The surge of oil price had shifted supply curve to left and then inflation elevated (Branson, 1979). This occurrence was supported as another type of cost-push inflation; as being prominent as the supply-shock inflation (Dwivedi, 2010).

Inflation in industrial countries is mostly supported by demand-pull and cost-push inflation theories but these theories do not completely cover the reasons of inflation in developing countries (Jung \& Marshall, 1986). For this reason, the structural inflation theory has provided the basic understanding of the original causes of inflation in the economic structure. Some studies address the fiscal constraints of government and the foreign exchange limits as most significant structural causes of inflation in developing countries. Their problems refer to inappropriate tax and subsidy systems and also limited and insufficient capital markets. These limitations drive governments to finance deficits through other ways particularly money creation, thereby the monetary authority's control over inflation is limited. (Ghatak \& Sánchez-Fung, 1995; Kirkpatrick \& Nixson, 1987; Tanzi, 1978).

In 1981, Sargent and Wallace illustrated the fiscal dominance phenomenon as new causes of inflation particularly in developing countries. They state that in a monetarist economy, the monetary authority independently determines seigniorage and can control inflation. But the monetary authority's control over inflation is limited when the fiscal authority dominates the monetary authority. It depicts that government applies a simple way to finance its debts by forcing the central bank to print money.

Generally, most of the empirical studies have applied the monetary model to study inflation. A famous monetary model is provided by Harberger(1963) and applied to clarify Chilean inflation. Moreover it has been applied to Asian countries by Sadeghi, Samsami, \& Sherafat(2007),Tavakkoli \& Karimi (1999), Sheehey (1979) and Saini (1982).

After the oil crisis in 1973, some studies augment the monetary inflation model with adding cost push inflation factors such as price of oil and exchange rate and im- 
ported goods (Bahmani-Oskooee,1995; Bairam (1990); Cuñado and Pérez de Gracia, 2003; Darrat; Arize, 1990).

Many studies in developing countries have contributed the structural models to clarify the reasons of inflation. They explain the relationship between macroeconomic variables and inflation.Ghatak \& Sánchez-Fung (1995),Baer (1987),Jung \& Marshall (1986),Sargent and Wallace (1981)Prebisch (1970) and Sunkel (1960)are examples of studies that have used the structuralist model of inflation.

In the last decade, apart from the study of the causes of inflation, some studies such as Noriega and Ramos-Francia (2009) and Caporin and Gupta (2017) focus on the analyses of the inflation persistence especially in the USA. They state the persistence of inflation is crucial to the mechanism of monetary transmission, and determines its success in keeping a stable level of economic growth and inflation, simultaneously. It also makes up an imperative component in the formulation of an optimal and beneficial monetary policy. From the other point of view, discovering whether the inflation persistence has dropped is critical in determining the probability of recidivism via the monetary authority (Sargent, 2001, Gadea \& Mayoral, 2005).

Iran has encountered the problem of rising inflation. Figure 1 illustrates an average inflation in Iran at 19.3\% compared with low and high income, and Middle East countries which worth $8.8 \%, 3.6 \%, 7.34 \%$ respectively from 1981 to 2011 (World Bank, 2012). In 1995, Iran's inflation reached its highest rate at almost 50\% partly.

Figure 1: Inflation in 1981-2011

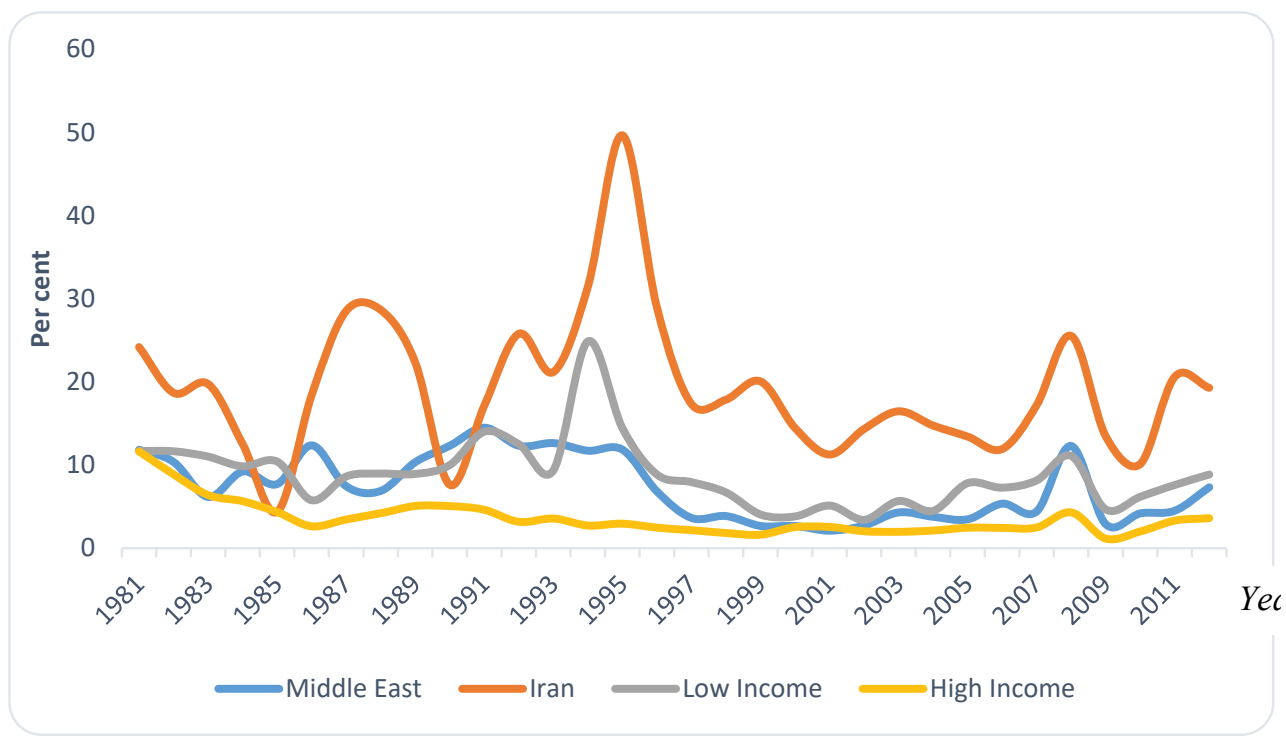

Source: World Bank (2012) 
The statistical data show that the government has not achieved its goals to control or reduce the money supply growth throughout five years development plans since 1988.Incorrectly, government has increased its expenditures continuously although it receives more income from oil sector for many years. Subsequently it finances its budget deficits by forcing the central bank (Bonato, 2007).

Moreover, Figure 2 displays the Phillips curve in Iran since Iranian revolution in 1979 to 2011.The result indicates that the 1\% increase in real GDP decreases inflation $0.67 \%$. The negative impact of real GDP on inflation is confirmed by estimation although R-square is low (20\%). It means that a decrease in real GDP augments inflation (stagflation). The result conflicts with our expectation from the Phillips curve; hence it shows the Iran's inflation is also related to supply side besides demand side.

Figure 2: Inflation and Real GDP in Iran (1979-2011/ since revolution)

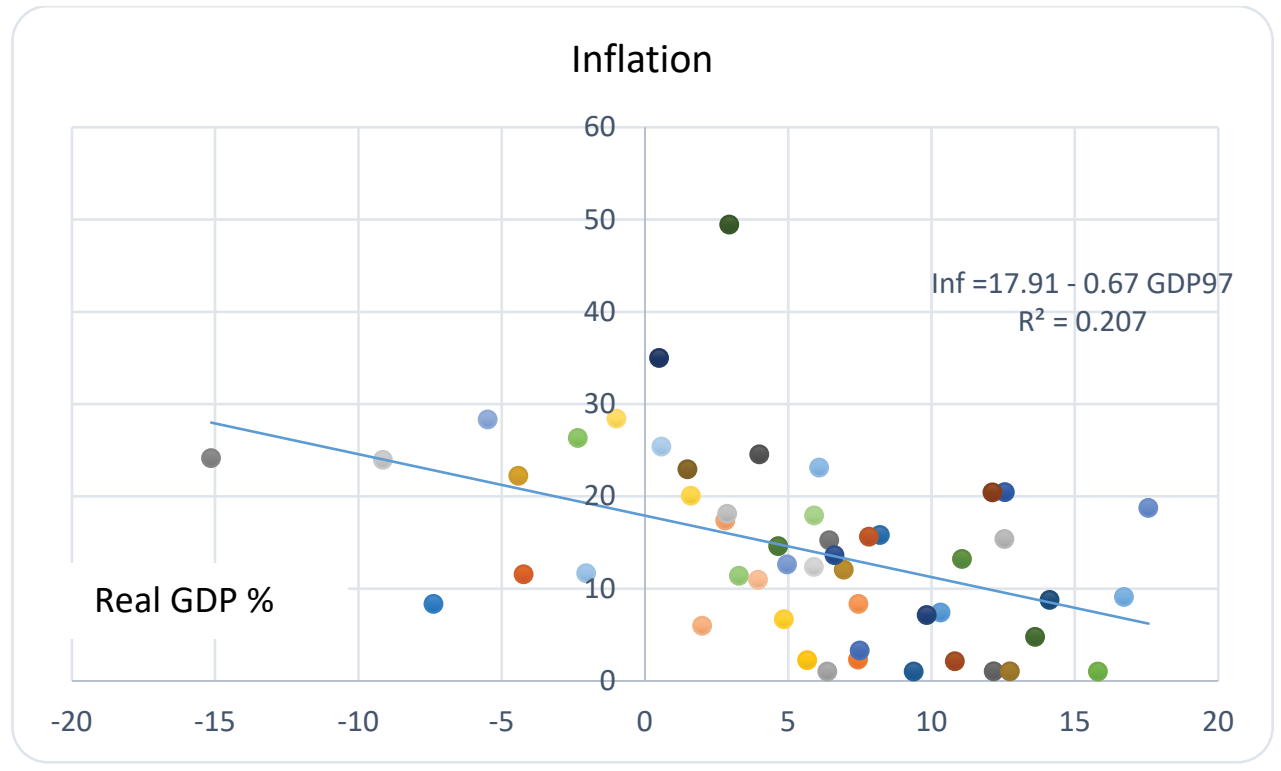

Most researchers have found analytical models which include monetary and costpush inflation (Bahmani-Oskooee, 1995; Bonato, 2007) or monetary and structural inflation (Samimi \& Jamshidbaygi, 2011; Tekin-Koru \& Özmen, 2003) particularly in Iran. However it is necessary to construct models which contain the vital factors of all these three theories such as money supply, real GDP, oil price, exchange rate, budget deficit.

Furthermore, most of the models just concern about the relationship between the market exchange and inflation; while there is a lack of study about the impact of official exchange rate on inflation. For example there is the huge difference between 
official exchange rate and market (black) exchange rate from 1977 to 2001. The difference ranged from 0 to 6879 Rials.This gap can impact inflation as well.

Apart from inflation causes, study on inflation persistence has attracted much attention for economists and monetary authorities in the last decade particularly in the USA; namely, Noriega and Ramos-Francia (2009) and Cogley, Primiceri, and Sargent (2010). They believe that adequate responses to inflation rely upon the degree of inflation persistence. Hence monetary authorities need to know the degree of inflation persistence so that they can fight with inflation by applying the optimal monetary policy. Measuring of inflation persistence responds to these two main questions of the Iranian economy;(1) how far are monetary policies from their optimal degree at which they can control inflation?; (2) which shock has more impact on inflation; the permanent or temporary one?

\section{Research Methodology}

\section{Variables and Data}

This study analyzes the reasons of inflation in Iran and has chosen the sample period data from 1970 to 2011. The main variables of this research are Consumer Price Index (P), broad money (M2), real gross domestic products (GDP97) (base 1997=100), market exchange rate (MEXRATE), official exchange rate (OEXRATE), price of oil (PO), and budget deficit (BD). All variables are transformed into natural logarithm form, except budget deficit. Budget deficit is based on the percentage of nominal GDP. Moreover, Data have been collected from Central Bank of Iran (CBI).

\section{Conceptual Frameworks}

With respect to the objectives, this study has divided the causes of inflation into two categories including internal and external in Figure 3. Internal causes include money supply, real GDP, exchange rate, and budget deficit while external causes are oil price and economic sanctions. Moreover the impact of exchange rate on inflation is studied from two points of view which are market exchange rate and official exchange rate. The effect of economic sanctions on inflation is studied through dummy sanctions

Apart from the causes of inflation, conceptual framework illustrates the impact of the monetary policies against inflation. Therefore, this study measures the inflation persistence to realize how far are monetary policies from the optimal level of being able to control inflation. 
Figure 3: Conceptual Framework

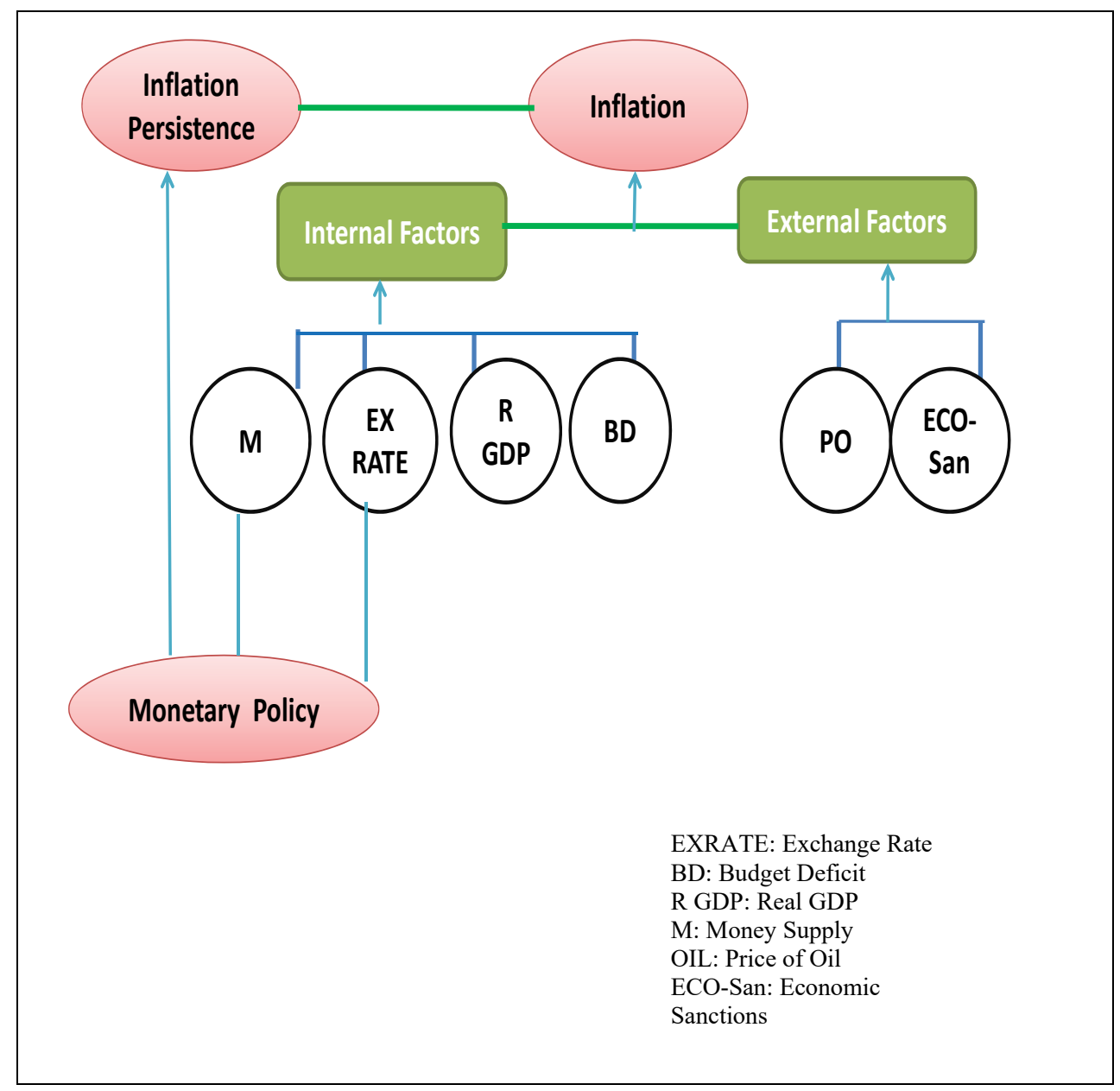

Analytical framework

Figure 4 illustrates the appropriate methods of analyzing each objective. First, EngleGranger test and the Autoregressive Distributed Lag Modeling (ARDL) are applied to analyze the response of inflation to its determinants in objective 1 (Obj1). 
Figure 4: Analytical Framework

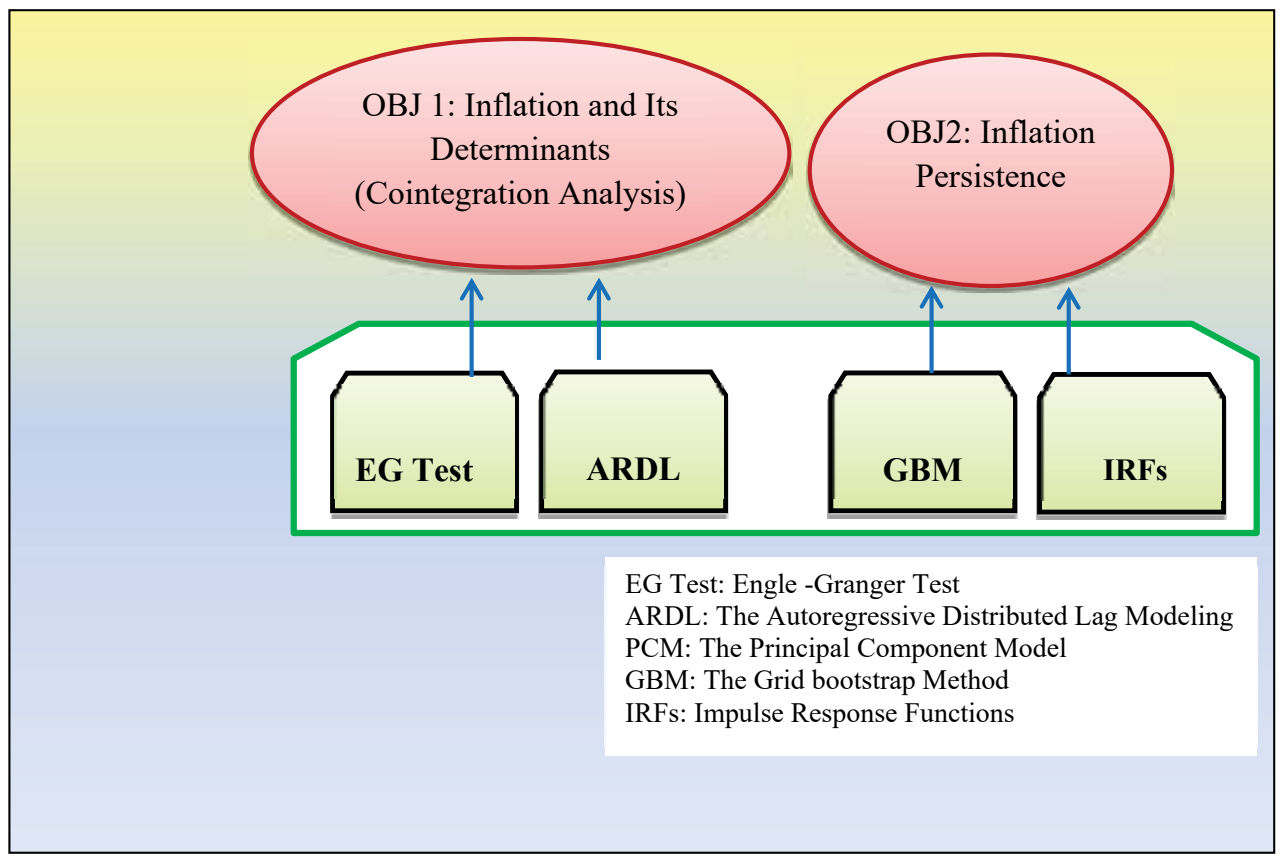

Two models are applied to cover objective 1 (Obj1) with respect to inflation theories such as demand-pull, cost-push, and structural inflation. We expand the previous studies of Bahmani-Oskooee (1995), Bonato (2007) and Armesh, Salarzehi, and Mohammad (2010) in Iran. With mixed order of integration in the variables, Engle and Granger (1987),Pesaran and Shin (1998), and Pesaran et al. (2001) suggest applying the multi-co-integration models including Engle-Granger Testand Autoregressive Distributed Lag (ARDL).

Apart from causes of inflation, the role of monetary policies on inflation is taken into account in objective 2. Following Hansen (1999),Levin, Natalucci, and Piger (2004) and Capistrán and Ramos-Francia (2009), we apply the Grid bootstrap Method (GBM), and Impulse Response Functions (IRF) to measure the inflation persistence $\left(\pi \_t\right)$. In GBM model, optimal monetary policy is a function of inflation persistence. The GBM estimates the $\beta$ coefficient as inflation persistence in autoregressive (AR) model as follows.

$$
\left\{\begin{array}{l}
\text { Inflation Persistence }=\operatorname{GBM}\left(\pi_{t}\right) \\
\pi_{t}=\alpha+\beta \pi_{t-1}+\sum_{k=1}^{m} \beta_{k} \Delta \pi_{t-k}+\varepsilon_{t}
\end{array}\right.
$$


The augmented Dickey-Fuller (ADF) unit root testis applied to determine the order of integration. But there is a concern which may data has structural break. It may lead to choose not appropriate methods to analyze the models. So, to remove this problem except ADF test, is applied the structural of Zivot and Andrews (2002) test to analyze the unit test with structural breaks.Except precondition for time series data we test residual diagnostics. The main diagnostic tests are the serial correlation, normality, functional form, and heteroscedasticity. Furthermore, to choose the optimal lag it concerns the Akaike's Information Criterion (AIC) test.

\section{Findings and Discussion}

\section{Unit Root Tests}

The ADF unit root test is performed on the level series with a constant, and a constant with a time trend.Only a constant term is included in the unit root test with first difference. The number of lags of the dependent variable in the ADF test is chosen based on the AIC. Table 1 illustrates the null hypothesis of unit root in all the level series cannot be rejected by the ADF statistics as the values are not large enough. Using an intercept and lagged on first-difference of dependent variable, the first difference ADF statistics are calculated. When first-differenced data are applied, the existence of unit root is rejected for all the variables. The ADF statistics, $\tau_{-} \mu$ on all the series are very high statistically significant at $1 \%$ and $5 \%$ level.

Table 1: Unit Root Tests (1970-2011)

\begin{tabular}{|c|c|c|c|c|c|c|c|c|c|c|c|c|}
\hline \multirow{3}{*}{ Series } & \multicolumn{6}{|c|}{$\begin{array}{c}\text { Augmented Dickey-Fuller (ADF) test } \\
H_{0} \text { : Unit Root }\end{array}$} & \multirow{2}{*}{\multicolumn{6}{|c|}{$\begin{array}{c}\text { Zivot-Andrews test } \\
H_{0}: \text { Unit Root and Structural Break } \\
\text { Level }\end{array}$}} \\
\hline & \multicolumn{4}{|c|}{ Level } & \multicolumn{2}{|c|}{ Difference } & & & & & & \\
\hline & $k$ & $\tau_{\mu}$ & $k$ & $\tau_{\tau}$ & $k$ & $\vartheta_{\mu}$ & $k$ & $\tau_{\mu}$ & $\begin{array}{l}\text { Structural } \\
\text { Break } \\
\text { (Year) }\end{array}$ & $k$ & $\vartheta_{\tau}$ & $\begin{array}{l}\text { Structural } \\
\text { Break } \\
\text { (Year) }\end{array}$ \\
\hline $\mathrm{P}$ & 2 & 0.13 & 1 & -2.33 & 0 & -4.06 **** & 1 & \begin{tabular}{|l|}
-4.57 \\
\end{tabular} & 1994 & 1 & -5.02 & 1994 \\
\hline M2 & 1 & -0.85 & 1 & -2.74 & 0 & $-3.31 * *$ & 3 & $-5.89 * * *$ & 1984 & 3 & $-5.22 * *$ & 2000 \\
\hline GDP97 & 4 & 1.15 & 5 & -0.96 & 5 & $-3.38 * *$ & 1 & -4.02 & 1980 & 1 & $-4.84 * *$ & 1986 \\
\hline MEXRATE & 2 & -1.17 & 1 & -1.86 & 1 & $-3.61 * *$ & 3 & -3.21 & 2005 & 3 & -4.73 & 1994 \\
\hline OEXRATE & 0 & -0.29 & 0 & -2.38 & 0 & $-6.19 * * *$ & 0 & $-6.37 * * *$ & 1992 & 0 & $-9.37 * * *$ & 1992 \\
\hline $\mathrm{PO}$ & 0 & -2.46 & 0 & -2.50 & 0 & $-5.98 * * *$ & 0 & -3.55 & 1986 & 0 & -2.81 & 2005 \\
\hline $\mathrm{BD}$ & 0 & -2.69 & 0 & -2.87 & 0 & $-8.23 * * *$ & 0 & -4.91 & 1989 & 0 & -4.91 & 1989 \\
\hline
\end{tabular}

Notes: 1. P, M2, GDP97, MEXRATE, OEXRATE, PO, and BD are the consumer price index, real gross domestic product, the exchange rate, the official exchange rate, the gap between official and market exchange rate, the price of oil and budget deficit, respectively.

2. ***and $* *$ represent significant level at $1 \%$ and $5 \%$, respectively. 
3. The Augmented Dickey Fuller test statistics are computed with an intercept, a liner time trend and $k$ lagged first-difference of the series to the series in level. The ADF regression in first-differences, exclude a liner time trend. The lag length $(\mathrm{k})$ was selected based on Akaike Information Criteria (AIC). Atn=50, the ADF critical values are $-3.58(1 \%),-2.93(5 \%)$ and $-2.60(10 \%)$ for constant ()$;-4.15(1 \%),-3.50(5 \%)$ and $-3.18(10 \%)$ for a constant and time trend ().

4. The ZA tests are based on the null hypothesis of unit root. The optimal lag length $(\mathrm{k})$ is selected based upon the t-significance approach as suggested by $\mathrm{Ng}$ and Perron (1995). The ZA critical values are $-3.34(1 \%),-4.80(5 \%)$ and $-4.58(10 \%)$ for a constant ()$;-5.57(1 \%),-5.08(5 \%)$ and $-4.82(10 \%)$ for a constant and time trend ().

The ADF unit root test displays low power when a series is confronted with structural break. To circumvent this problem, Zivot-Andrews' (ZA) unit root test is utilized here. The results of ZA test for all variables in the level with a constant $\left(\vartheta_{-} \mu\right)$ and a constant and trend $\left(\vartheta \_\tau\right)$. Interestingly, the results suggest that there is a unit root in P, MEXRATE, PO, and BD series despite provisions for possible structural breaks. However, the test is unable to detect the presence of unit root in M2, OEXRATE and GDP97. In other words, the null hypothesis of unit root is rejected for M2, OEXRATE and GDP97 at 5\% significance level. Hence, P, MEXRATE, PO, and BD areI(1) and M2, OEXRATE and GDP97 are I(0). In the case of broad money (M2), it is noted that the break dates occurred at 1984 and 2000. While, the break dates occurred at 1992 for OEXRATE and for GDP97 at 1986. The ZA unit root test proves that some of the variables are stationary in the level form with structural breaks.

\section{Cointegration Analysis: Engle-Granger (EG) Test}

We already apply the ADF and ZA unit root tests. All we should estimate the regressions such as equation 1 and 2,find the residuals, and use the ADF test.

$$
\begin{aligned}
& \mathrm{P}=-6.6+0.68 \mathrm{M} 2+0.18 \text { GDP97 + 0.20 MEXRATE }-0.32 \mathrm{PO}+0.004 \mathrm{BD} \\
& \mathrm{t}=(-2.53) \\
& \text { R-squared }=0.99 \quad \mathrm{DW}=1.34 \\
& \Delta U_{t}=-0.003-0.71 U_{t-1} \\
& \mathrm{t}=\quad(-0.29) \quad(-4.84) \\
& \text { R-squared }=0.34 \quad \mathrm{DW}=1.95 \\
& \mathrm{P}=0.61+0.87 \mathrm{M} 2-0.45 \mathrm{GDP} 97+0.042 \text { OEXRATE }-0.34 \mathrm{PO}+0.01 \mathrm{BD} \\
& \mathrm{t}=(0.47) \\
& \text { R-squared }=0.99 \quad \mathrm{DW}=1.34 \\
& \Delta U_{t}=-0.001-0.73 U_{t-1} \\
& \mathrm{t}=\quad(-0.14) \quad(-4.79) \\
& \text { R-squared }=0.37 \quad \mathrm{DW}=1.95
\end{aligned}
$$


Equation 1 and equation 2 illustrate the most important variables to increase inflation are money supply (M2) and market exchange rate. Budget deficit also increases inflation. While price of oil and real GDP decrease it. Market exchange rate rises inflation 4.7 times bigger than official exchange rate $(0.20 / 0.042=4.76)$. It means inflation decreases when the monetary authorities apply the official exchange rate instead of market exchange rate.

As we have realized some variables such as P and GDP97 are non-stationary in the level (see table 1); these regressions are possibly spurious. Granger notes, "A test for co-integration can be thought of as a pre-test to avoid 'spurious regression' situations". But when we make a unit root test on the residuals obtained from equation 1 and equation 2. The Engle-Granger 1 percent critical value is -4.85 in question 1.A and -4.79 in equation 2.A.As the computed values are much more negative than this, our conclusion is that the residuals from the regression are $\mathrm{I}(0)$; that is, they are stationary. Hence, question 1 and 2 are co-integrating regressions and these regressions are not spurious, while some variables are individually non-stationary. Equation 1 and 2 are as the long-run inflation functions. They explain its parameters such as long-run parameters.

\section{Cointegration Analysis: ARDL Bound Test}

Table 2 demonstrates the ARDL bound test for cointegration analysis. Both models include broad money (M2), real GDP (GDP97), price of oil (PO) and budget deficit (BD) as the independent variables that explain the behavior of the consumer price index (P) in the models. Apart from the listed variables, models 1 includes the market exchange rate while model 2 the official exchange rate. A dummy sanction is added in both models as an external factor of inflation.

Table 2: Bounds Test: Long-run Relationship Analysis (1970-2011)

\begin{tabular}{|c|c|c|c|}
\hline Period: 1970- 2011 & $\begin{array}{l}\text { Computed } \\
\text { F-statistic }\end{array}$ & $\begin{array}{l}\text { Bound Critical } \\
\text { Values } \\
\mathrm{I}(0) \quad \mathrm{I}(1)\end{array}$ & $\begin{array}{l}\text { Serial } \\
\text { Correlation } \\
\text { (AR) }\end{array}$ \\
\hline Model 1:F(PIM2,GDP97,MEXRATE,PO,BD,DSAN) & $5.31 * * *$ & {$\left[\begin{array}{ll}2.82 & 4.21\end{array}\right]$} & $1.94(0.37)$ \\
\hline Model 2:F(PIM2,GDP97,OEXRATE,PO,BD,DSAN) & $3.48 * *$ & {$\left[\begin{array}{ll}2.14 & 3.34\end{array}\right]$} & $3.95(0.13)$ \\
\hline
\end{tabular}

Note: 1. .P, M2, GDP97, MEXRATE, OEXRATE,PO, BD, DREV and DSAN are the consumer price index, broad money, real GDP, the market exchange rate, the official exchange rate, price of oil, budget deficit, and a dummy for sanction.

2. The number of independent variables is 5 for all the models, $\mathrm{k}=5$. The selected lag is 2 for all the models based on AIC selection and diagnostic tests especially Lagrange multiplier (LM) statistic for testing the hypothesis of no residual serial correlation. Asymptotic critical value bounds test is based on the assumption that the variables are $\mathrm{I}(0)$ and $\mathrm{I}(1)$ Pesaran et al. (2001); The asterisks ***, **, and * denote significance level at $1 \%, 5 \%$ and $10 \%$ respectively.

3. AR is Breusch-Godfrey serial correlation test. 
Table 2 shows the computed F-statistic for the two models with the critical bound values $^{1}$. The computed F-statistic are 5.31, 3.48 which are bigger than the upper critical bounds value, 4.21, 3.34, respectively. Comparison between the computed F-statistic and the critical upper value for each model suggests that there is a long-run co-integration vector for each model.

\section{Long-run and Short-run Dynamic Analysis}

Table 3 provides findings on the long-run and short-run relationship between inflation and factors that affect inflation in Iran based on the ARDL estimation. Referring to two models, a $1 \%$ increase in broad money causes an increase of $0.93 \%$ and $0.85 \%$, in inflation in the long run, respectively. In other words, on average a $1 \%$ increase in broad money will increase inflation about $0.89 \%$ in the long run. Thus, all the models prove broad money is one of the main causes of inflation in Iran. The increase of broad money has a direct effect on the demand side. It shifts the demand curve to the right. If supply side fails to accommodate this extra demand, pressure will be built up on prices and the economy will face inflation. With the existence of supply constraint in the Iranian economy the increase in broad money increases inflation considerably.

From the long-run relationship analysis, the minimum and maximum values of budget deficit among the models are between 0.014 and 0.017 . This justifies that another main cause of inflation is budget deficit. The budget deficits increase the government's debts and to solve this, the government resorts to quantitative easing method. This approach only increases demand side while supply side still unable to accommodate with the extra demand of goods and services. Hence, inflation increases. 
Table 3: The Response of Inflation to its Determinants (1970-2011)

\begin{tabular}{|c|c|c|}
\hline & $\begin{array}{c}\text { Model } 1 \\
\text { ARDL }(2,0,0,1,1,1) \\
\end{array}$ & $\begin{array}{c}\text { Model } 2 \\
\text { ARDL }(2,0,0,2,1,1) \\
\end{array}$ \\
\hline M2 & $\begin{array}{l}0.93 * * * \\
(11.06)\end{array}$ & $\begin{array}{l}0.85 * * * \\
(28.83)\end{array}$ \\
\hline GDP97 & $\begin{array}{c}-0.38 * * * * \\
(-19.22)\end{array}$ & $\begin{array}{l}-038 * * * * \\
(-39.19) \\
\end{array}$ \\
\hline MEXRATE & $\begin{array}{c}-0.05 \\
(-0.39) \\
\end{array}$ & - \\
\hline OEXRATE & - & $\begin{array}{l}0.04 * \\
(1.78) \\
\end{array}$ \\
\hline $\mathrm{PO}$ & $\begin{array}{c}-0.43 * * * \\
(-4.46) \\
\end{array}$ & $\begin{array}{c}-0.36 * * * \\
(-9.62) \\
\end{array}$ \\
\hline $\mathrm{BD}$ & $\begin{array}{l}0.017 * * \\
(2.09)\end{array}$ & $\begin{array}{c}0.014 * * * * \\
(2.66) \\
\end{array}$ \\
\hline DSAN & $\begin{array}{c}0.19 \\
(0.92) \\
\end{array}$ & $\begin{array}{l}0.17 * * \\
(2.34) \\
\end{array}$ \\
\hline $\mathrm{dP}(-1)$ & $\begin{array}{l}0.22 * \\
(1.86) \\
\end{array}$ & $\begin{array}{l}0.24 * * \\
(2.14) \\
\end{array}$ \\
\hline $\mathrm{dM} 2$ & $\begin{array}{c}0.38 * * * \\
(4.74)\end{array}$ & $\begin{array}{c}0.44 * * * \\
(5.72)\end{array}$ \\
\hline dGDP97 & $\begin{array}{c}-0.15^{* * * *} \\
(-3.59) \\
\end{array}$ & $\begin{array}{c}-0.20 * * * \\
(-5.65) \\
\end{array}$ \\
\hline dMEXRATE & $\begin{array}{c}0.07 \\
(1.09) \\
\end{array}$ & - \\
\hline dOEXRATE & - & $\begin{array}{l}0.011 \\
(0.76) \\
\end{array}$ \\
\hline dOEXRATE(-1) & - & $\begin{array}{l}-0.029 * \\
(-1.84) \\
\end{array}$ \\
\hline $\mathrm{dPO}$ & $\begin{array}{l}-0.06^{*} \\
(-1.96) \\
\end{array}$ & $\begin{array}{l}-0.08^{* *} \\
(-2.39)\end{array}$ \\
\hline dBD & $\begin{array}{c}0.00 \\
(0.083) \\
\end{array}$ & $\begin{array}{c}0.0019 \\
(0.59) \\
\end{array}$ \\
\hline ECT(-1) & $\begin{array}{l}-0.41^{* * * *} \\
(-4.14) \\
\end{array}$ & $\begin{array}{c}-0.51^{* * * *} \\
(-6.05) \\
\end{array}$ \\
\hline dDSAN & $\begin{array}{c}0.07 \\
(1.04) \\
\end{array}$ & $\begin{array}{l}0.08^{* * *} \\
(2.52) \\
\end{array}$ \\
\hline Diagnostic Tests & $\begin{array}{l}\mathrm{R}^{2}=0.66, \overline{\mathrm{R}}^{2}=0.55 \\
\mathrm{~F}-\mathrm{Stat}=8.35(0.00) \\
\mathrm{SC}=0.11(0.73) \\
\mathrm{FF}=2.56(0.109) \\
\mathrm{N}=0.33(0.84) \\
\mathrm{H}=0.20(0.88)\end{array}$ & $\begin{array}{l}\mathrm{R}^{2}=0.69, \overline{\mathrm{R}}^{2}=0.57 \\
\mathrm{~F}-\mathrm{Stat}=8.09(0.00) \\
\mathrm{SC}=0.57(0.44) \\
\mathrm{FF}=0.006(0.93) \\
\mathrm{N}=1.48(0.47) \\
\mathrm{H}=1.65(0.19)\end{array}$ \\
\hline
\end{tabular}

Note 1.P, M2, GDP97, MEXRATE, OEXRATE, ,PO, BD and DSAN are the consumer price index, broad money, real GDP, the market exchange rate, the official exchange rate, price of oil, budget deficit, and a dummy sanction.

2. Wald tests have confirmed there are the long run relationships between inflation and its determinants in the two models in 1970-2011 yearly. Maximum of 2 lags is used for the models with respect to AIC tests and the results of diagnostic tests. 
3. Figures in parentheses are t-values; the asterisks $* * *, * *$, and $*$ denote significance at the $1 \%, 5 \%$ and $10 \%$ levels, respectively.

4. There are $\mathrm{SC}=$ serial correlation, $\mathrm{FF}=$ function form, $\mathrm{N}=$ =normality and $\mathrm{H}=$ =heteroscedasticity;

The effect of market exchange rate on inflation is not evident in the long-run relationship. Because t-statistic is -0.34 and value is very much lower than the conventional significance level of 0.01 . Therefore, we utilize the official exchange rate (OEXRATE) instead of the market exchange rate (MEXRATE) in Model 2. Interestingly by replacing the market exchange rate with the official exchange rate, models 2 illustrates positive effect of the official exchange rate on inflation in the long run. A $1 \%$ increase in the official exchange rate causes an increase of $0.04 \%$ in inflation.

On the contrast, the effect of oil price shocks on inflation is negative in both models. A $1 \%$ increase in the price of oil reduces inflation by $0.43 \%$ and $0.36 \%$ respectively. The negative effect of oil price shocks on inflation is the result of government subsidy on oil. Iran is the second largest oil exporting country after Saudi Arabia in the OPEC. Large revenues from oil income enable the government to have subsidy program. Thus, generally oil prices are stable in Iran because of subsidy. Increases of oil prices do not have much inflationary pressure in Iran instead prices fall.

Unlike other studies, real GDP has a similar effect as oil prices. Inflation decreases with a rise in real GDP in both models. Interestingly, when economic sanctions are considered in the models, inflation is also responding positively to economic sanctions. From Model 2, evidence from the long-run relationship shows that inflation increases by $0.17 \%$ when economic sanctions are present.

The findings on the short-run relationship between inflation and its determinants are given in Table 3. Generally, broad money, real GDP, oil price and inflation have the expected sign in both models. On average, a $1 \%$ increase in broad money increases inflation by $0.41 \%$ in all the models. The effect is more than half of its effect in the long-run relationship $(0.89 \%)$.

The negative impact of real GDP on inflation in the short run is almost half $(0.175 \%)$ than its effect in the long run $(0.38 \%)$ in models. An increase of $1 \%$ oil price decreases inflation on average by $0.07 \%$ in the short run. Budget deficit and the market exchange rate have very small t-values therefore their impact on inflation is not significant in the short run. While a $1 \%$ increases of the official exchange rate decreases inflation by $0.029 \%$ with a one year delay in short run. Basically the official exchange rate is operating like the fixed exchange rate system. Interestingly, the findings offer more evidence on the response of inflation to official exchange rate. Because it reduces inflation in short run and increases inflation in long run. It was happened because official exchange rate has increased from 1992 to 1994 and from 2002 to 2011 considerably. Economic sanctions (DSAN) have positive effect on inflation. The effect is almost half (0.08) in the short run compared to the long-run estimates (0.17). This shows that the sanction takes longer time to have its effect on inflation. 
More information` on the short-run dynamics can be explained from the speed of adjustment to the equilibrium in the system and this is measured by the value of the magnitude of ECT. The ECT coefficient is highly statistically significant at $1 \%$ level in all the models and it has the right sign. The value ranges are between 0.41 and 0.51 ; this explains that on average inflation adjusts by almost $45.5 \%$ at $1 \%$ significant level to close the gap in bringing back the economy to equilibrium. The convergence to the equilibrium is moderate and not rapid.

Several measures of diagnostic tests are applied to check whether the estimations of the constructed models have the desirable statistical properties. The heteroskedasticity test reveals that the errors are homoskedastic and is independent of regressors. The Breusch-Godfrey test shows that there is no significant serial correlation in the disturbance of the error terms. Jarque-Bera statistic shows the residuals are well behaved, the disturbances are normally distributed.

\section{Inflation Persistence}

Figure 5 shows the inflation rates from 1970 to 2011. The maximum and minimum of inflation are 49.46 and 4.76. While the mean and standard deviation of inflation is 17.46 and 8.87 . This study utilizes two approaches, namely grid bootstrap method and impulse response functions to measure inflation persistence.

Figure 5: Inflation1970-2011

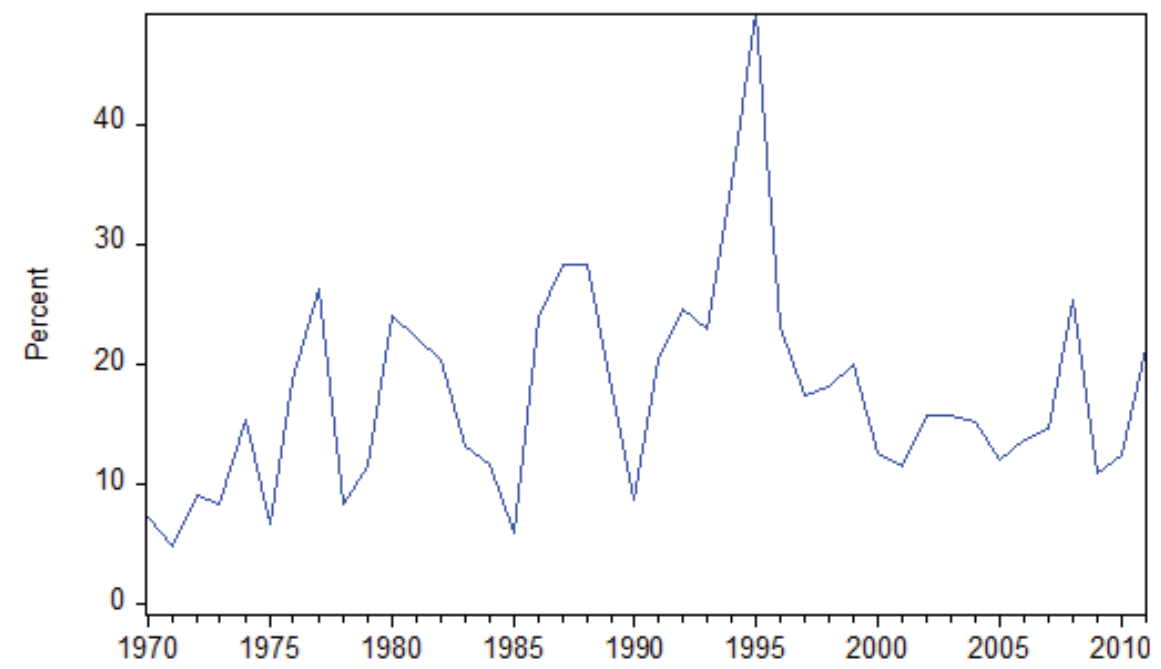


Table 4 demonstrates the result of inflation persistence by the grid bootstrap method. The optimal lag is one based on AIC test and diagnostic tests especially the residual serial correlation LM test ${ }^{2}$. The inflation persistence value is 0.46 at $90 \%$ grid-t confidence interval. 'According to Grelach and Tillmann (2012), if the absolute value of $\beta$ is smaller than unity, $|\beta|<1$, it means that the procedure is stationary and there exists at least some effective monetary policy for controlling inflation. Moreover, $\widehat{\beta}=\frac{(\mathrm{T}-1) \sigma_{\rho}^{2}}{(\mathrm{~T}-1) \sigma_{\rho}^{2}+\sigma_{\vartheta}^{2}}=\frac{46}{100}$ in which $\sigma_{\vartheta}^{2}$ is the variance of the temporary inflation shock and $\sigma_{\rho}^{2}$ is the permanent shock. It shows that permanent shocks are smaller than temporary shocks. Based on the argument, the effects of monetary policy on stabilizing Iran's inflation are somewhat effective.

Table 4: Inflation Persistence in Iran (1970-2011)

\begin{tabular}{|l|c|c|c|c|c|}
\hline Sample & Mean & Standard Deviation & Lag & $\beta$ & $90 \%$ Grid-t \\
\hline $1970-2011$ & 17.46 & 8.67 & 1 & 0.46 & {$\left[\begin{array}{ll}0.30 & 0.88\end{array}\right]$} \\
\hline
\end{tabular}

Notes: The table reports Hansen's (1999) mean unbiased estimator of the sum of autoregressive coefficients, $\beta$ and the bootstrapped $90 \%$ confidence bands based on 200 grid points and 3000 replications conditional on breaks in the intercept term. The lag order is chosen according to the AIC and residual serial correlation.

The confidence interval shows that $\beta$ is within 0.30 and 0.88 at $90 \%$ grid-t confidence interval. The estimate (0.46) suggests that the influence of monetary policy controlling inflation is far from its optimal level. When $\beta=0$, monetary authorities have implemented optimal monetary policy and the permanent shocks are fully control by the monetary policy.

Finally, Figure 6 illustrates the construction of the percentile-t and grid confidence intervals. The solid down-ward sloping line is the t-statistic function. The dashed lines are 5\% and 95\% bootstrap quantile functions, which are clearly quite nonlinear in $\beta$. The open circles denote the intersection points, and the black arrows indicate the endpoints of the grid-t interval. The percentile-t intervals can be read using the dotted lines, which show how the percentile-approximates the bootstrap quantile functions by flat lines at the OLS estimate $\hat{\beta}$. The open arrows denote the percentile-t end points. From the OLS estimate $\hat{\beta}=0.46$, the dotted lines move vertically to the $5 \%$ and $95 \%$ bootstrap quantile functions, with the intersections marked by the open diamonds. From these points, the dotted lines move horizontally to the $\mathrm{t}$-statistic functiont $(\beta)$. The points of intersection, marked by open rectangles, are the percentile-t bootstrap endpoints. These are projected onto the $\mathrm{x}$ axis and marked by the white arrowheads. This $90 \%$ percentile-t bootstrap interval is [ $\left.\begin{array}{lll}0.30 & 0.88\end{array}\right]$. 
Figure 6: 90\%- Confidence Interval for (Inflation)

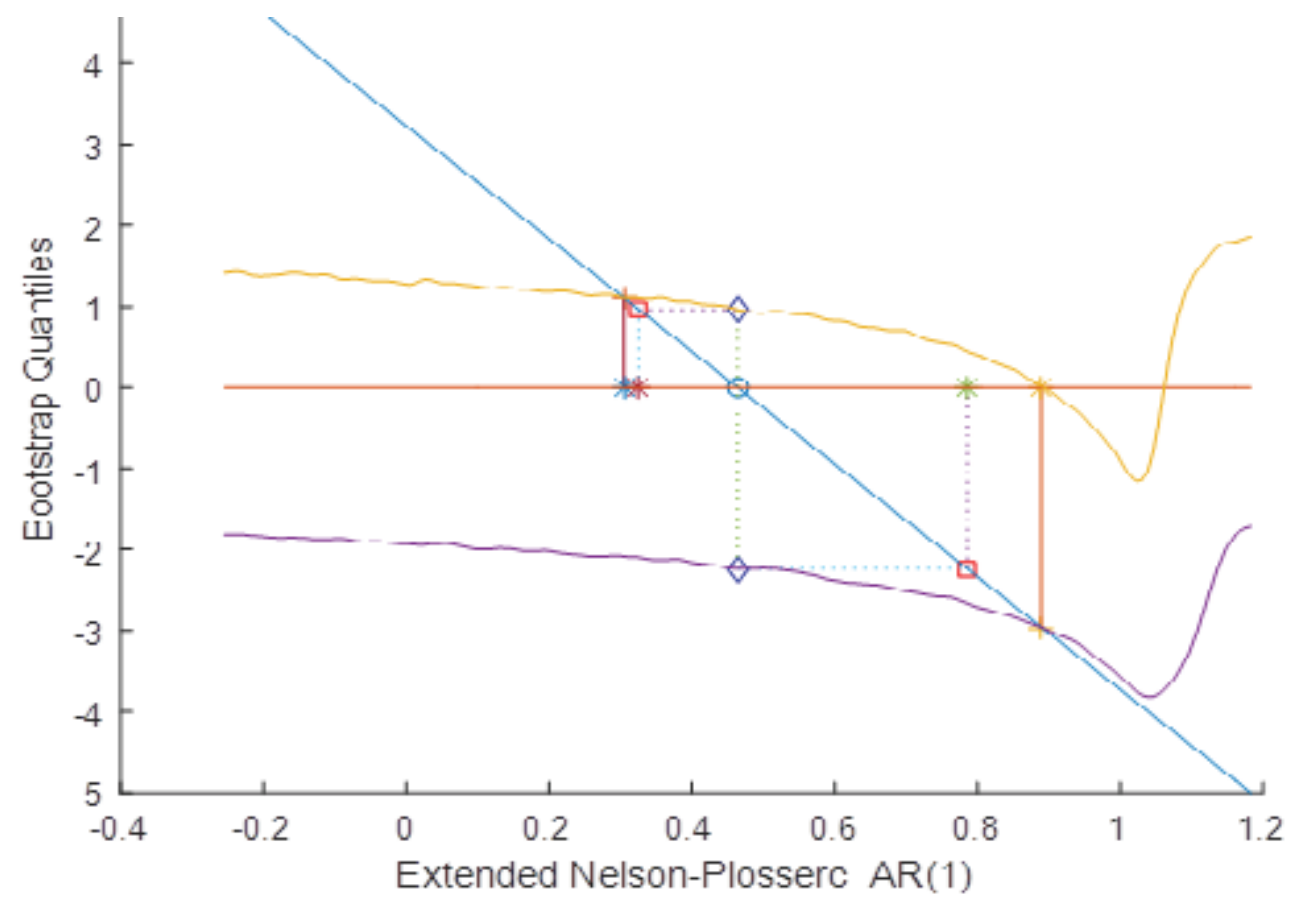

Note: The dashed lines are the $5 \%$ and $95 \%$ bootstrap quantile functions. The solid line is the t-statistic function.,The intersections mark the endpoints of the grid-t confidence interval. The linear projections mark the endpoints of the percentile-t interval.

Second approach to measure inflation persistence is impulse response functions (IRF). Figure 7 and Table 6 show nearly 53\% of inflation to one standard error shock to inflation decreases after a year. Similarly, the effect of a one-unit shock of inflation to inflation reduces almost 52\% in each year and reaches to zero after 10 years. Interestingly the coefficient of GBM, , and the average amount of inflation dropped in each period in IRFs, 0.52 ,state the same judgment about inflation persistence. 
Figure 7 and Table 6 :Response of Inflation to Inflation Innovation

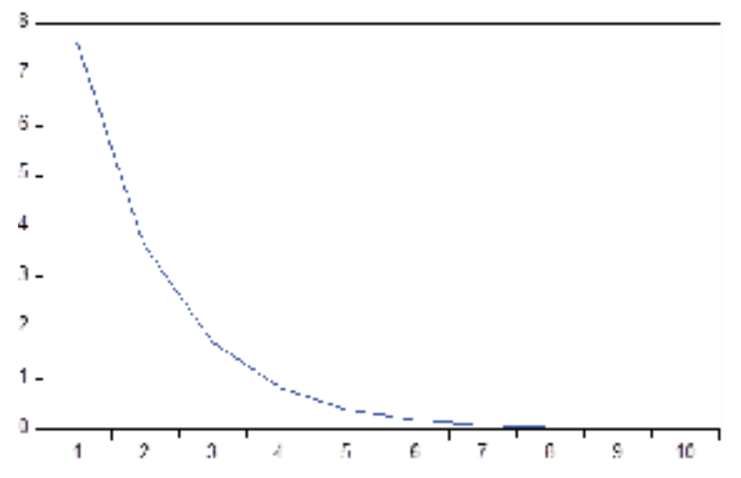

\begin{tabular}{cc}
\hline \hline Period & \\
\hline \hline 1 & 7.633520 \\
2 & 3.635291 \\
3 & 1.731225 \\
4 & 0.824457 \\
5 & 0.392629 \\
6 & 0.186981 \\
7 & 0.089045 \\
8 & 0.042406 \\
9 & 0.020195 \\
10 & 0.009617 \\
\hline \hline
\end{tabular}

In other words, the results of these two methods show inflation persistent is not the unit root because the estimated and the confidence interval do not include the unity. Hence inflation persistence follows the structural changes and finally permanent shocks die out after some horizons. It shows monetary authorities are trying to control inflation by monetary policy but their monetary policies are yet far from optimal level. Low inflation persistence helps to maintain low inflation because shocks that trigger inflation now would have a less prolonged influence on the rate of inflation in the following period (Zhang \& Clovis, 2009).

\section{Conclusion}

This study suggests that controlling money supply is the key factor to control inflation in Iran. Although to some extent monetary policy remained effective in attaining inflation targets, it was incapacitated to manage inflation to single-digit level. Therefore, monetary policy has remained inadequate to subdue inflation and other monetary targets set in the Development Plans in Iran. The challenge is how to control the money supply effectively.

The appreciation of Rial exchange rate is an important factor of lower inflation. The results advocate that the fixed exchange rate is an appropriate exchange rate regime to control inflation. There exists a direct relationship between budget deficits and inflation and sources of government income are such as oil revenues and income taxes. The Kuwait's experience can be used along with the tax reforms to finance budget deficit of the Iranian government. Mehrara (2007) study shows an interesting experience of Kuwait budget deficit. The country has successfully stabilized its inflation and formed saving fund called the General Reserve Fund (GRF) as a measure of self-insurance to deal with volatile revenues. 
Inflation persistence follows the structural changes and finally permanent shocks die out after some horizons. It shows monetary authorities are trying to control inflation by monetary policy but their monetary policies are yet far from optimal level.

\section{NOTES}

${ }^{1}$ The critical bound values are given by Pesaran et al. (2001). Follow Pesaran and Shin (1998), the selected optimal lag for each model is two based on AIC selection and diagnostic tests. The results of AR show that all the models have no serial correlations and therefore Wald test (F test) is applied on each model.

${ }^{2} \mathrm{AIC}$ value for lag one is 6.94 and it is the smallest value among others. Serial Correlation: $=0.28(0.59)$.

\section{REFERENCES}

Armesh, H., Salarzehi, H., \& Mohammad, N. (2010). Causes of Inflation in the Iranian economy. International Review of Business Research Papers, 6(3):30-44.

Baer, W. (1987). The resurgence of inflation in Brazil, 1974-1986. World Development, 15(8), 10071034.

Bahmani-Oskooee, M. (1995). Source of inflation in post-revolutionary Iran. International Economic Journal, 9(2):61-72.

Bairam, E. (1990). Money and inflation: The case of western developed countries, 1960-80. Applied Economics, 22(7):863-869.

Baldwin, R. E. (1994). Towards an integrated Europe. Geneva: Graduate Institute of International Studies.

Bergeijk, P. A. G. (1994). Economic diplomacy, trade and commercial policy: Positive and negative sanctions in a New World Order. Vermont: Edward Elgar.

Bergeijk, P. A. G. (1995). The impact of economic sanctions in the 1990s. The World Economy, 18(3):443-455.

Bonato, L. (2007). Money and inflation in the Islamic Republic of Iran. Review of Middle East Economics and Finance. 4(1):41-58.

Buchanan, Friedman, Heckman, Koopmans, Lucas, \& Miller. (2013). Ideological profiles of the economics Laureates. Econ Journal Watch, 10(3):255-682.

Branson, W. H. (1979). Macroeconomic theory and policy (Vol. 3). New York: Harper \& Row.

Caporin, M., \& Gupta, R. (2017). Time-varying persistence in US inflation. Empirical Economics, 53(2), 423-439.

Cogley, T., Primiceri, G. E., \& Sargent, T. J. (2010). Inflation-gap persistence in the U.S. American Economic Journal: Macroeconomics, vol:43-69. NBER Working Paper No. w13749. Retrieved from: http://papers.ssrn.com/sol3/papers.cfm?abstract_id=1087002

Cuñado, J., \& Pérez de Gracia, F. (2003). Do oil price shocks matter? Evidence for some European countries. Energy Economics, 25(2):137-154.

Darrat, A. F., \& Arize, A. C. (1990). Domestic and international sources of inflation in developing countries: Some evidence from the monetary approach. International Economic Journal, 4(4), 55-69. 
Drezner, D. W. (2000). Bargaining, enforcement, and multilateral sanctions: when is cooperation counterproductive? International Organization, 54(1), 73-102.

Dwivedi, D. (2010). Macroeconomics, 3E: New Delhi: Tata McGraw-Hill.

Gadea, M., \& Mayoral, L. (2005). The persistence of inflation in OECD countries: A fractionally integrated approach. International Journal of Central Banking, 1(1):51-104.

Gerlach, S., \& Tillmann, P. (2012). Inflation targeting and inflation persistence in Asia-Pacific. Journal of Asian Economics, 23(4), 360-373.

Engle, Robert F.; Granger, Clive W. J. (1987). "Co-integration and error correction: Representation, estimation and testing”. Econometrica. 55 (2): 251-276.

Friedman, M. (1977). Inflation and unemployment. Journal of Political Economy, 85(3):451-472.

Granger, C. W., \& Newbold, P. (1974). Spurious regressions in econometrics. Journal of Econometrics, 2(2):111-120.

Ghatak, S., \& Sánchez-Fung, J. R. (1995). Monetary economics in developing countries. London: Palgrave Macmillan.

Hansen, B. E. (1999). The grid bootstrap and the autoregressive model. Review of Economics and Statistics, 81(4):594-607.

Harberger, A. C. (1963). The dynamics of inflation in Chile (No. 14).Dept. of Economics, Graduate School of Business:University of Chicago.

Hufbauer, G. C., Schott, J. J., \& Elliott, K. A. (1990). Economic sanctions reconsidered: Supplemental case histories. Washington: Institute for International Economics.

Jung, W. S., \& Marshall, P. J. (1986). Inflation and Economic Growth: Some International Evidence on Structuralist and Distortionist Positions: Note. Journal of Money, Credit and Banking, 18(2):227-232.

Lee, K., Ni, S., \& Ratti, R. A. (1995). Oil shocks and the macroeconomy: The role of price variability. The Energy Journal, 16(4):39-56.

Levin, A. T., Natalucci, F. M., \& Piger, J. M. (2004). The macroeconomic effects of inflation targeting. Federal Reserve Bank of St. Louis Review, 86(4):51-80.

Kirkpatrick, C., \& Nixson, F. (1987). Inflation and stabilization policy in LDCs. Surveys in Development Economics. Oxford: Basil Blackwell.

Mehrara, M., \& Oskoui, K. N. (2007). The sources of macroeconomic fluctuations in oil exporting countries: A comparative study. Economic Modelling, 24(3):365-379.

Ng, S., \&Perron,P. (1995): "Unit Root Tests in ARMA Models with Data Dependent Methods for the Selection of the Truncation Lag," Journal of the American Statistical Association, 90, 268281.

Noriega, A. E., Capistrán, C., \& Ramos-Francia, M. (2009). On the dynamics of inflation persistence around the world. Empirical Economics, 44(3):1243-1265.

Pape, R. A. (1997). Why economic sanctions do not work. International Security, 22(2):90-136.

Sadeghi-Boroujerdi, E. (2012). Sanctioning Iran: Implications and consequences. Oxford: Oxford Research Group.

Sadeghi, M., Samsami, H., \& Sherafat, N. (2007). Inflation-targeting exchange rate policy for an oil producing country: The case of Iran. Macquarie University Research Online.

Samimi, A. J., \& Jamshidbaygi, S. (2011). Budget Deficit and Inflation: A Sensitivity Analysis to Inflation and Money Supply in Iran. Middle-East Journal of Scientific Research, 8(1):257-260.

Sargent, T. J. (2001). The conquest of American inflation. New Jersey: Princeton University Press.

Sargent, \& Wallace, N. (1981). Some unpleasant monetarist arithmetic. Federal Reserve Bank of Minneapolis Quarterly Review, 5(3):1-17.

Sheehey, E. J. (1979). On the measurement of imported inflation in developing countries. Weltwirtschaftliches Archiv, 115(1), 68-80. 
Saini, K. G. (1982). The monetarist explanation of inflation: The experience of six Asian countries. World Development, 10(10), 871-884.

Pesaran, M. H., \& Shin, Y. (1998). An autoregressive distributed-lag modelling approach to cointegration analysis. In Storm. S. (Ed.). Econometrics and Economic Theory in the 20th Century: The Ragnar Frisch Centennial Symposium. Edinburgh: Cambridge University Press.

Pesaran, M. H., Shin, Y., \& Smith, R. J. (2001). Bounds testing approaches to the analysis of level relationships. Journal of Applied Econometrics, 16(3):289-326.

Prebisch, R. (1970). Structural Vulnerability and Inflation. In Meier. G. (Ed.). Leading Issues in Economic Development: Studies in International Poverty (pp. 238-241). Oxford: Oxford University Press.

Romer, D. (1993). Openness and inflation: Theory and evidence. The Quarterly Journal of Economics, 108(4):869-903.

Sunkel, O. (1960). Inflation in Chile: an unorthodox approach. International Economic Papers, 10:107131.

Tanzi, V. (1978). Inflation, Real Tax Revenue, and the Case for Inflationary Finance: Theory with an Application to Argentina. IMF Staff Paper 25(3):417-451. Retrieved from: http://www.jstor. org/stable/3866679

Tavakkoli, A., \& Karimi, F. (1999). The Survey and Determination of Effective Factors on Inflation in Iran. Proceedings of 9th Conference on Monetary and Banking Policies, Central Bank of Iran.

Tekin-Koru, A., \& Özmen, E. (2003). Budget deficits, money growth and inflation: The Turkish evidence. Applied Economics, 35(5):591-596.

Torbat, A. E. (2005). Impacts of the US trade and financial sanctions on Iran. The World Economy, 28(3):407-434.

Zahrani, M. (2008). Sanctions against Iran. The Iranian Journal of International Affairs, 20(2):23-42.

Zhang, C., \& Clovis, J. (2009). Modeling China inflation persistence. Annals of Economics and Finance, 10(1):89-110.

Zivot, E., \& Andrews, D. W. K. (2002). Further evidence on the great crash, the oil-price shock, and the unit-root hypothesis. Journal of Business \& Economic Statistics, 20(1):25-44. 